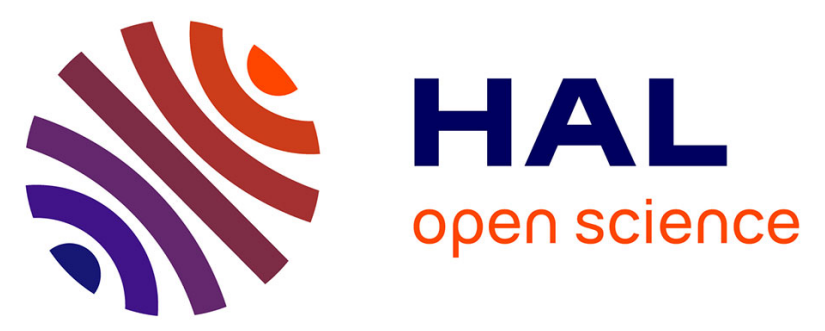

\title{
Structural and Thermodynamics Studies on Polyaminophosphonate Ligands for Uranyl Decorporation
}

Gaoyang Ye, Jérome Roques, Pier-Lorenzo Solari, Christophe den Auwer, Aurélie Jeanson, Jérémy Brandel, Loïc J. Charbonnière, Wangsuo Wu, Éric Simoni

\section{To cite this version:}

Gaoyang Ye, Jérome Roques, Pier-Lorenzo Solari, Christophe den Auwer, Aurélie Jeanson, et al.. Structural and Thermodynamics Studies on Polyaminophosphonate Ligands for Uranyl Decorporation. Inorganic Chemistry, 2021, 60 (4), pp.2149-2159. 10.1021/acs.inorgchem.0c02145 . hal-03186161

\section{HAL Id: hal-03186161 \\ https://hal.science/hal-03186161}

Submitted on 17 May 2021

HAL is a multi-disciplinary open access archive for the deposit and dissemination of scientific research documents, whether they are published or not. The documents may come from teaching and research institutions in France or abroad, or from public or private research centers.
L'archive ouverte pluridisciplinaire HAL, est destinée au dépôt et à la diffusion de documents scientifiques de niveau recherche, publiés ou non, émanant des établissements d'enseignement et de recherche français ou étrangers, des laboratoires publics ou privés. 


\section{Published in "Inorganic chemistry"}

\section{Structural and thermodynamic studies on polyaminophosphonate}

ligands for uranyl decorporation

Gaoyang Ye ${ }^{\mathrm{a}, \mathrm{f}}$, Jérome Roques ${ }^{\mathrm{a}}$, Pier-Lorenzo Solari ${ }^{\mathrm{b}}$, Christophe Den Auwer $^{\mathrm{c}}$, Jérémy

Brandel $^{\mathrm{d}}$, Loïc J. Charbonnière ${ }^{\mathrm{d}}$, Wangsuo $\mathrm{Wu}^{\mathrm{e}}$, and Éric Simoni ${ }^{\mathrm{a}}{ }^{*}$.

a. Institut de Physique Nucléaire d’Orsay, UMR8608, Universié Paris-Saclay, 91405 Orsay, France

b. MARS beamline, Synchrotron SOLEIL, 91192 Gif sur Yvette, France

c. Institut de Chimie de Nice, UMR7272,Université Côte d’Azur, CNRS, 06108 Nice, France

d. IPHC, UMR 7178, CNRS/ Université de Strasbourg, F-67000 Strasbourg, France

e. Radiochemistry Laboratory, Lanzhou University, 730000 Lanzhou, Gansu, China

f. Institute of Nuclear and New Energy Technology Tsinghua University, 100084 Beijing, China

*Email: yegaoyang@tsinghua.edu.cn 
Abstract: The development of actinide decorporation agents with high complexation affinity, high tissue specificity and low biological toxicity is of vital importance for the sustained and healthy development of nuclear energy. After accidental actinides intake, sequestration by chelation therapy to reduce acute damage is considered as the most effective method. Here a series of bisand tetra-phosphonated pyridine ligands have been designed, synthesized and characterized for the uranyl decorporation. Owing to the absorption of ligand and the luminescence of uranyl ion, UVVis spectroscopy and Time-resolved Laser-induced Fluorescence Spectroscopy (TRLFS) were used to probe in-situ complexation and structure variation of the complexes formed by the ligands with uranyl. Density functional theory (DFT) calculation and X-ray absorption fine structure (XAFS) spectroscopy on uranyl ligand complexes revealed the different coordination geometries around the uranyl center at $\mathrm{pH} 3$ and 7.4. High affinity constants ( $\operatorname{LogK} \sim 17$ ) towards uranyl ion were determined by displacement titration. In vitro chelation study proves that bis-phosphonated pyridine ligands can remove uranium from calmodulin (CaM) at low-dose and short-term which supports the further uranium decorporation applications of these ligands.

Keywords: Thermodynamic; Structural; Actinides; Phosphonate-based ligands; Uranyl; Decorporation 
With the development of nuclear energy industry, the manipulation and accumulation of uranium lead to consider uranium decorporation after possible accidental contamination. The hexavalent uranyl ion $\left(\mathrm{UO}_{2}{ }^{2+}\right)$ is the most stable form in aqueous solutions and sera. ${ }^{1}$ After an external or internal contamination, the solubilized actinides could be distributed to the target organs via the bloodstream. Uranyl ion preferentially transfers to the skeletal, liver and kidneys tissues and is retained at these target organs. ${ }^{2}$ Due to the chemo-toxicity and radio-toxicity, the acute effect on health could cause death and the long-term effect will result in cancer, anemia and necrosis. ${ }^{3}$ In order to limit sequence damage to organs, chelating agents with high stability constant and high selectivity towards the uranyl ion were used to promote the uranium excretion from the target organs. The resulting uranyl complexes should also be soluble in the biological conditions in order to be excreting by urine or bile. ${ }^{4,5}$

Up to now, several ligands were proved to be efficient for uranium decorporation with acceptable side effects. ${ }^{6-9}$ According to Pearson's rules, $\mathrm{UO}_{2}{ }^{2+}$ ion is defined as a hard acid, thus it prefers to react with hard bases like phosphonate anions. 1-hydroxyethane-1,1-diphosphonic acid (HEDP) is used in clinics for uranium(VI) decorporation due to the high affinity of bisphosphonates towards uranyl ion. ${ }^{10}$ Many phosphonate ligands which are designed for uranium decorporation could complex uranyl ion tightly, but, unfortunately, after in vivo tests only a few of them could reduce the uranium retention. Furthermore, the toxicities of these ligand are needed to be considered in order to pass the clinical trial.,9

Therefore, we envisaged a series of multidentate phosphonated pyridine ligands for the uranium decorporation study. These ligands were originally designed for the formation of magnetic resonance imaging (MRI) contrast agent and for imaging by Single-Photon Emission Computed Tomography (SPECT) ${ }^{11,12}$ Experiments carried out on mice with ${ }^{99 \mathrm{~m}}$ Tc and the bis-phosphonated 
ligand $\mathbf{L}^{\mathbf{1}}$ and tetra-phosphonated ligand $\mathbf{L}^{2}$ (Figure 1) have shown that the complexes formed with $\mathbf{L}^{\mathbf{1}}$ could rapidly be excreted though the kidneys and bladder while those of the tetra-phosphonated ligand $\mathbf{L}^{2}$ were fixed on the bone tissues. ${ }^{11}$ A further test with the $\mathrm{Gd}^{3+}$ complex of ligand $\mathbf{L}^{2}$ revealed a fast clearance in blood, while the contrast was distributed to kidneys, liver and muscle. Along the experiment, the mouse could tolerate the administration of contrast. ${ }^{13}$ Meanwhile the complex of $\mathrm{Eu}^{3+}$ with ligand $\mathbf{L}^{2}$ showed that the ligand could offer four five-membered chelate rings at the equatorial planner ${ }^{12}$ which is well suited for uranyl ion coordination. Considering the fast excretion, low toxicity and high affinity, phosphonated pyridine ligands designed for uranyl ion coordination could represent a promising alternative for implantation in uranium decorporation studies.

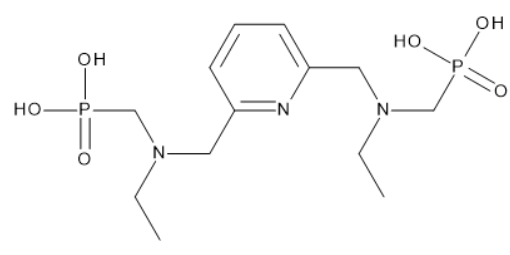

$\mathbf{L}^{1}$

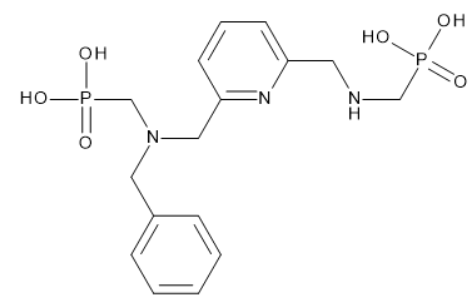

$\mathbf{L}^{3}$

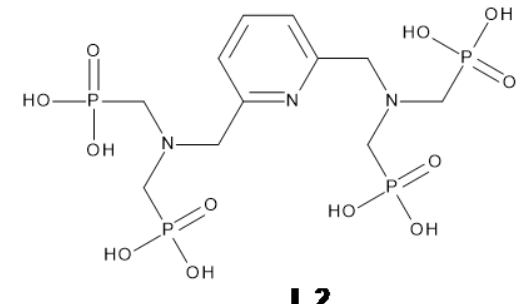

$\mathbf{L}^{2}$

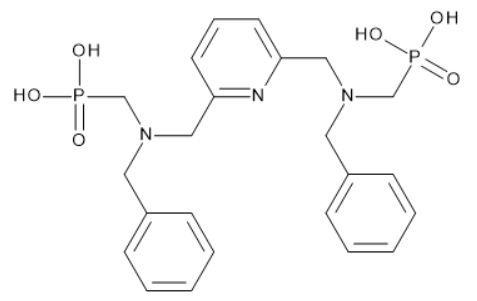

$\mathbf{L}^{4}$

Figure 1. Bis-phosphonated ligand $\mathbf{L}^{1}, \mathbf{L}^{3}, \mathbf{L}^{4}$ and tetra-phosphonated ligand $\mathbf{L}^{2}$ 
In this study, two pentadentate bis-phosphonated pyridine ligands, $\mathbf{L}^{3}$ and $\mathbf{L}^{4}$ (Figure 1), bearing 5 donor atoms for an equatorial planar coordination, were designed and synthesized to improve lipophilic property and oral efficiency. ${ }^{4,5,14}$ Structural and thermodynamic studies were performed for the two bis-phosphonated ligands, $\mathbf{L}^{3}$ and $\mathbf{L}^{4}$, and the tetra-phosphonated ligand $\mathbf{L}^{2}$ (Figure $\mathbf{1}$ ). In addition, the stability of the uranyl-ligand complex obtained with $\mathbf{L}^{4}$ was tested by competition with cations, and a calmodulin (CaM) chelation study with ligand $\mathbf{L}^{4}$ support potential implantation in decorporation.

\section{Results}

\section{Design and synthesis of the ligands.}

The synthesis of bis-phosphonated ligand $\mathbf{L}^{3}$ and $\mathbf{L}^{4}$ (Figure 2) was adapted from known preparations of phosphonated pyridine ligand. ${ }^{11} \mathbf{L}^{3}$ and $\mathbf{L}^{4}$ were obtained by bromination of the commercially available 2,6-dihydroxymethylpyridine 1 with $\mathrm{PBr}_{3}$ at $0^{\circ} \mathrm{C}$, affording 2,6dibromomethylpyridine $\mathbf{2}$ in 95\% yield. Diethyl ((benzylamino)methyl)phosphonate 3 was obtain from benzylamine in two step (Figure 2). To a stirred solution of benzylamine, formaldehyde was added to get 1,3,5-Tribenzylhexahydrotriazine 2 in 91\% yield. ${ }^{15}$ The intermediate compound 3 was synthesized by reaction of 2 with diethylphosphite in $42 \%$ yield. ${ }^{16} \mathrm{~N}$-alkylation reaction of $\mathbf{1}$ with $\mathbf{3}$ resulted in the formation of the bis-phosphonated ester 4 (79\%) which led to ligand $\mathbf{L}^{4}$ (52\%) after hydrolysis of phosphonate groups using $6 \mathrm{M} \mathrm{HCl}$. Interestingly, the hydrolysis also resulted in the partial deprotection of the benzyl groups, with formation of the mono-benzylated ligand $\mathbf{L}^{3}$ (13\%), together with minute amounts (9\%) of the bis deprotected ligand analogue. 


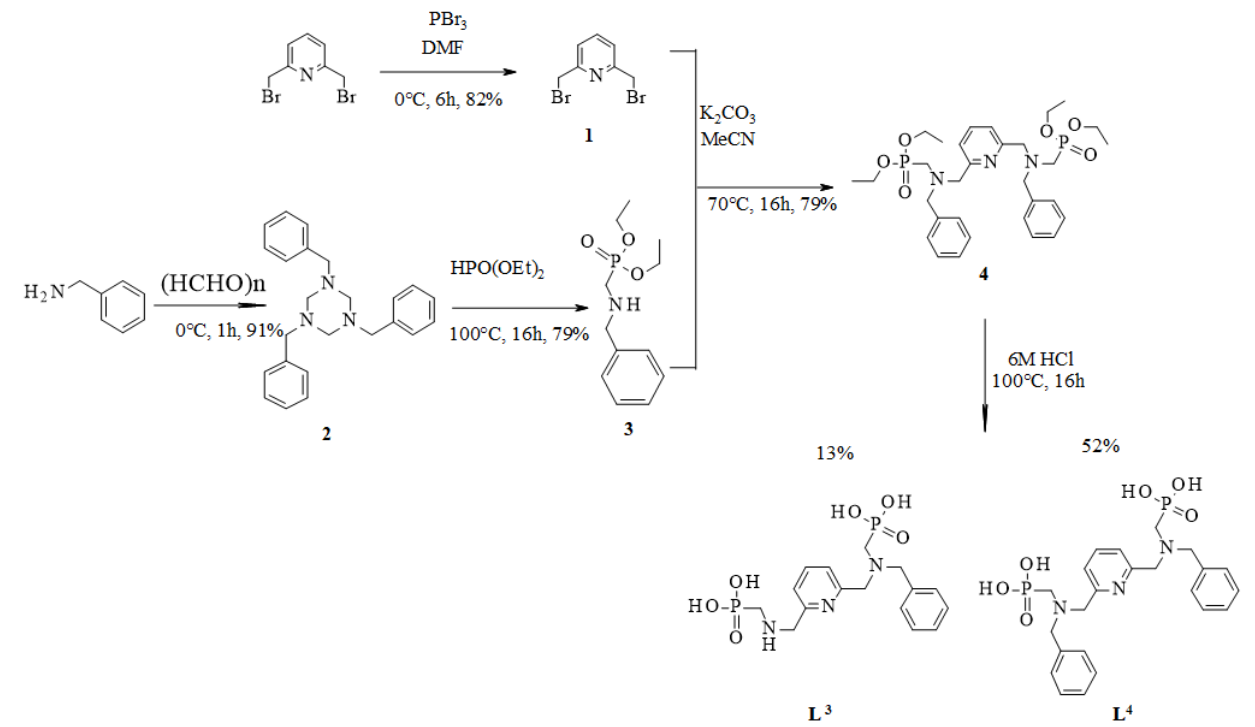

Figure 2. Synthesis of the ligands (fully protonated species)

\section{Protonation of ligands $L^{3}$ and $L^{4}$.}

$\mathbf{L}^{3}$ and $\mathbf{L}^{4}$ have a homogeneous series of chelating units with 2 terminal $-\mathrm{PO}_{3}{ }^{2-}$ phosphonate functions, two amines and a pyridyl ring. The difference between the two ligands is the number of benzylene moieties which might result in the different on complexation affinity difference with uranyl ion.

Investigation of the complexation of uranyl ions with the ligands require the complete characterization of ligand protonation. Therefore, the acido-basic properties of $\mathbf{L}^{3}$ and $\mathbf{L}^{4}$ were investigated in the $\mathrm{pH}$ range $2.0-12$ by potentiometry. Potentiometric titrations of $\sim 1 \mathrm{mM}$ solutions of $\mathbf{L}^{3}$ or $\mathbf{L}^{4}$, followed by statistical processing of the data with the HYPERQUAD softaware ${ }^{18-20}$ resulted in the determination of four protonation constants for each ligand (Table 1). The other 
non-characterized protonation constants are associated with much lower values $\left(\log \mathrm{K}_{\mathrm{LHx}}<<2\right.$ ) which couldn't be detected under our experimental conditions. The two most basic protonation constants $\mathrm{K}_{\mathrm{LH}}$ and $\mathrm{K}_{\mathrm{LH} 2}$ were attributed to the aliphatic amines, in agreement with data that existing in the literature for other polyaminomethanephosphonate analogues. ${ }^{11,20-26}$ It can be noted that the preplacement of a secondary amine in $\mathbf{L}^{3}$ by a benzylated tertiary one in $\mathbf{L}^{\mathbf{4}}$ did not had much influence on the correspondin pK values. The third and fourth protonation constants determined for the ligands are associated with the first protonation constants of each of the methanephosphonate groups. The two protonation constants, $\mathrm{p} K_{1}{ }^{\mathrm{H}}$ and $\mathrm{p} K_{2}{ }^{\mathrm{H}}$, could be assigned as the hydrogen which bond to the nitrogen on the side arms.

Table 1. Successive Protonation Constants of ligands $\mathbf{L}^{3}$ and $\mathbf{L}^{4}$

$\begin{array}{lrcc}\mathrm{pK}_{n}{ }^{\mathrm{H}} & & \mathbf{L}^{3} & \mathbf{L}^{\mathbf{4}} \\ \mathrm{p} K_{1}{ }^{\mathrm{H}} & \mathrm{N}_{\mathrm{ali}} & 9.5(1) & 9.28(5) \\ \mathrm{p} K_{2}{ }^{\mathrm{H}} & \mathrm{N}_{\text {ali }} & 9.15(1) & 8.91(6) \\ \mathrm{p} K_{3}{ }^{\mathrm{H}} & \mathrm{RPO}_{3} \mathrm{H}^{-} & 6.17(6) & 6.36(8) \\ \mathrm{pK}_{4}{ }^{\mathrm{H}} & \mathrm{RPO}_{3} \mathrm{H}^{-} & 4.6(2) & 4.45(5)\end{array}$

Solvent: $\mathrm{H}_{2} \mathrm{O} ; \mathrm{I}=0.1 \mathrm{M} \mathrm{NaClO}_{4} ; \mathrm{T}=25.0(2)^{\circ} \mathrm{C}$. The values in parentheses correspond to the standard deviations expressed as the last significant digit.

The distribution diagram of the protonated species for ligands $\mathbf{L}^{\mathbf{3}}$ (Supplementary Figure 3) and $\mathbf{L}^{4}$ (Figure 3 ) as a function of the $\mathrm{pH}$ of the solution are very similar. It shows that, under acidic conditions $(\mathrm{pH}<4), \mathbf{L}^{3}$ and $\mathbf{L}^{4}$ mainly exists as their neutral zwitterionic $\left[\mathbf{L H}_{4}\right]$ species while under physiological conditions ( $\mathrm{pH} 7.4)$, the deprotonated form $\left(\left[\mathbf{L H}_{2}\right]^{2-}\right)$ with two protonated aliphatic amines is predominant ( $\sim 80 \%)$. As a comparison, it can be noted that, for ligand $\mathbf{L}^{2}$, the $\left[\mathrm{LH}_{3}\right]^{5-}$ species was predominant under the same conditions. ${ }^{11}$

In order to establish the ligand spectrophotometric properties as a function of the $\mathrm{pH}$, a spectrophotometric titration was performed for ligand $\mathbf{L}^{4}$. The electronic spectra of the different 
protonated $\mathbf{L}^{4}$ species were obtained by fitting spectrophotometric titration data with protonation constants deduced by potentiometric titrations (Figure 3). The pyridine unit is the main chromophore considering the nature of ligand and displays and absorption with maximum around 262-270 nm, attributed to its $\pi-\pi^{*}$ transitions. ${ }^{27}$ Starting from basic $\mathrm{pH}$, the most significant variations were observed when the aliphatic amines were protonated, with the observation of an hypsochromic and hypochromic shift of the absorption band, together with the appearance of an hyperfine structure. These phenomena are to be related with an hydrogen bond formation between the ionizable site of the pyridinyl unit and the protonated side arms of the ligands. ${ }^{11}$
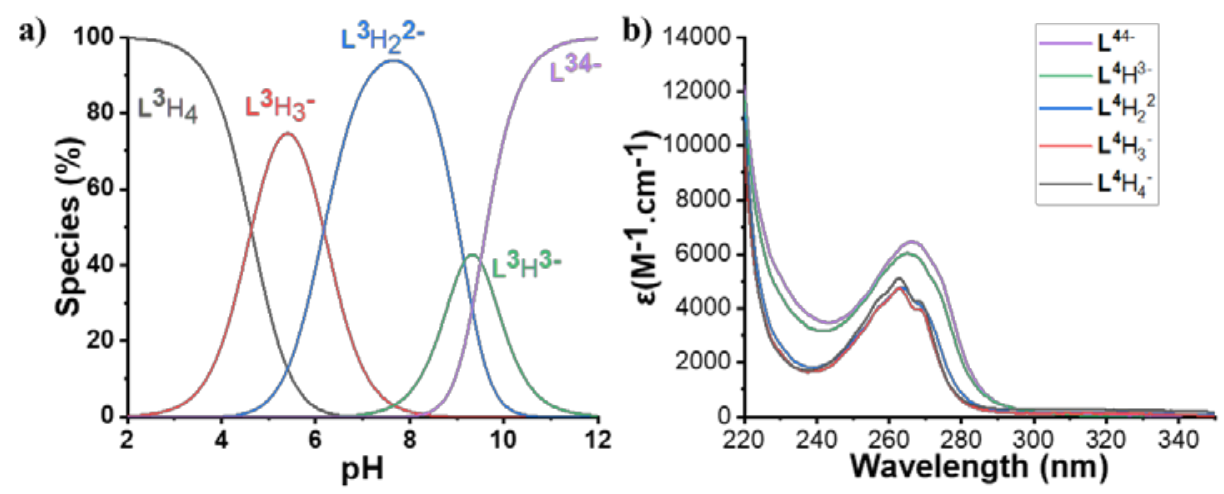

Figure 3. (a) distribution diagram and (b) Electronic spectra of different species of $\mathbf{L}^{4}$; Solvent:

$\mathrm{H}_{2} \mathrm{O}, \mathrm{T}=25.0(2)^{\circ} \mathrm{C}, 0.1 \mathrm{M} \mathrm{NaClO}_{4}, \mathrm{l}=1 \mathrm{~cm}$.

Commenté [C7]: The notation should be homogeneized $=>\mathbf{L}^{4} \mathrm{H}_{\mathrm{x}}{ }^{\mathrm{z}}$ not $\mathrm{H}_{\mathrm{x}}\left(\mathbf{L}^{4}\right)^{\mathrm{z}}$

\section{UV-Vis and TRLFS spectroscopic studies.}

A first study on uranyl-ligand complex was performed with UV-Vis spectroscopy and TRLFS at two distinct pHs, pH 3 and 7.4 (biological pH). Literature data on the uranyl-calmodulin complex have shown that, at $\mathrm{pH} 3$, a coordinated water molecule in the uranyl environment is deprotonated to form a hydroxide at $\mathrm{pH} 6 .^{28}$ Thus the study at $\mathrm{pH} 3$ is important to verify a possible coordination 
change of uranyl ion at biological $\mathrm{pH}$. Due to the low solubility of uranyl-ligand complex in $0.1 \mathrm{M}$ $\mathrm{NaClO}_{4}$ solution at acidic condition, $0.1 \mathrm{M} \mathrm{NaCl}$ solution was used for the sample preparation. Ligands $\mathbf{L}^{2}$ (4 phosphonates) and $\mathbf{L}^{4}$ (2 phosphonates) were selected owing to the difference on phosphonate moieties and symmetrical structure. The uranyl complexes with polyaminophosphonated ligands are expected to be informative spectroscopic probes thanks to the pyridine-centered $\pi-\pi^{*}$ transitions at $\sim 260 \mathrm{~nm}^{11}$, intense $\mathrm{N} \rightarrow \mathrm{UO}_{2}{ }^{2+}$ charge transfer absorption band $^{29}$ (280 - 340nm) and uranyl fluorescence around $520 \mathrm{~nm}$.

Significant changes were observed in the UV-vis absorption spectra of uranyl ligand complex whatever the pHs (Figure 4). The hyperchromic shift at $260 \mathrm{~nm}$ and the appearance of intense $\mathrm{N} \rightarrow \mathrm{UO}_{2}{ }^{2+}$ charge transfer bands in the 280-340 nm region indicate the formation of complexes upon addition of the uranyl ions. In almost all cases, the absorption bands at the maximum of absorption of the free ligands display linear variations (inset in Figure 4a, b, e and g), indicative of the formation of a 1:1 uranyl:lgand complex. Only in the case of $\mathbf{L}^{4}$ at acidic $\mathrm{pH}$ can we observe a two steps trend, with minor variations and the absence of MLCT absorption band up to 0.5 equivalents and strong variations from 0.5 to one equivalents of added uranyl ions. This trend is also corroborated by the observation by TRLFS. This behavior is indicative of the formation of two distinct species. In excess of ligand, a $\left[\left(\mathrm{UO}_{2}\right) \mathbf{L}^{4}{ }_{2}\right]$ would first be formed, followed by the appearance of the $\left[\left(\mathrm{UO}_{2}\right) \mathbf{L}^{4}\right]$ species after. Noteworthy, because of the presence of the four phosphonate functions, $\mathbf{L}^{4}$ is essentially present under the form of a doubly negatively charged ligand at $\mathrm{pH} 3.0{ }^{11}$ In contrast, as evidenced above, $\mathbf{L}^{2}$ will mostly be present as a zwitterionic neutral ligand, thereby explaining the lower affinity of the ligand for uranyl ions and the possibility to form species with two ligands per uranyl at this $\mathrm{pH}$. At $\mathrm{pH} 7.4$, the two phosphonate functions
Commenté [C9]: Add ref : "Luminescence sensing of uranyl by formation of supramolecular complexes with europium" Harvey, P.; Nonat, A.; Platas-Iglesias, C.; Natrajan, L.; Charbonnière, L.J. Angew. Chem. Int. Ed. 2018 , 57, 9921-9924.

Commenté [叶10R9]: The paper name is different with same authors. 
are deprotonated, leading to a doubly negatively charged ligand suitable for a stronger chelation in a 1:1 uranyl:ligand stoichiometry.

The pendant donors, 3 nitrogen atoms and 2 oxygen atoms, are provided by each ligand even with excess oxygen donors from phosphonates groups in $\mathbf{L}^{2}$. Hence the chelating ligand design is very well suited for the uranyl complexation.

The two different forms of uranyl ligand complex were further investigated by TRLFS (Figure

$\mathbf{4} \mathbf{b}, \mathbf{d}, \mathbf{f}$ and $\mathbf{h})$. The uranyl fluorescence is intense at $\mathrm{pH} 3$ after complexation compared to the free uranyl fluorescence in the same conditions (Supplementary Figure 4a). Meanwhile a strong hypsochromic shifts of $c a \sim 10 \mathrm{~nm}$ and $\sim 12 \mathrm{~nm}$ is observed for the uranyl- $\mathbf{L}^{2}$ and uranyl- $\mathbf{L}^{4}$ complexes, respectively, when compared to inorganic uranyl phosphates. ${ }^{30}$ The larger hypsochromic shift observed with $\mathbf{L}^{4}$ suggests a stronger interaction of uranyl ions with this ligand. However, no fluorescence could be observed for the studies at $\mathrm{pH} 7.4$ which also suggests a a strong coordination for the two ligands, as, in absence of ligand, the uranyl hydroxides have intense fluorescence in these conditions (Supplementary Figure 4b).

Due to no fluorescence property of uranyl ligand complex for Uranyl- $\mathbf{L}^{2}$ complex. Uranyl- $\mathbf{L}^{3}$ complex and uranyl- $\mathbf{L}^{4}$ at $\mathrm{pH} 7.4$ (Supplementary Figure 4), there is no uranyl hydroxide in the solution. By using HYSS software with uranyl ion hydrolysis constant ${ }^{31}$, it was possible to estimate the stability constants of uranyl- $\mathbf{L}^{2}$ complex. The formation constants of uranyl- $\mathbf{L}^{3}$ complex and uranyl-L $\mathbf{L}^{4}$ complex are higher than 13.3 to avoid uranyl hydroxide formation.

Commenté [C11]: Where is the value?

Commenté [0+12R11]: I did displacement test for L2. But its affinity is lower than SCP which couldn't get a precise value. Just know it below 15.3 according to marcin's paper 
a)

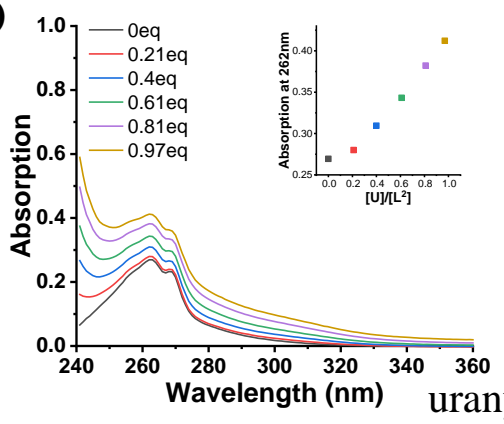

c)

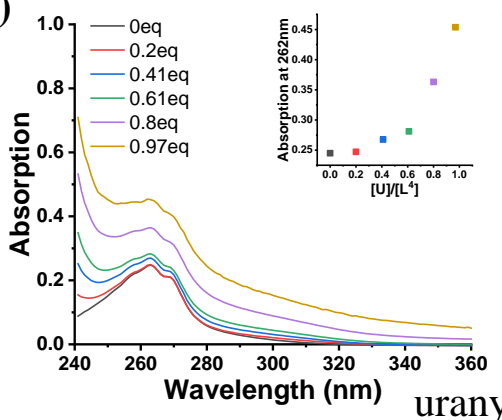

d)

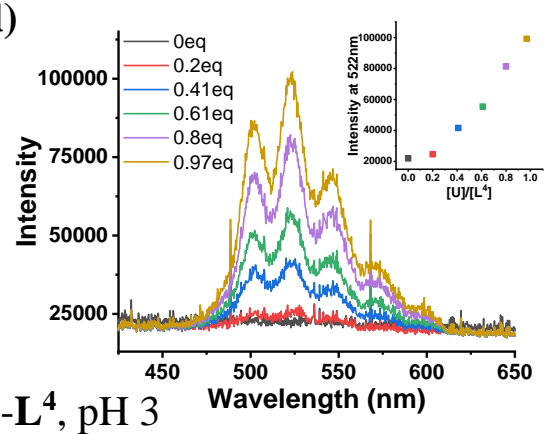

e)

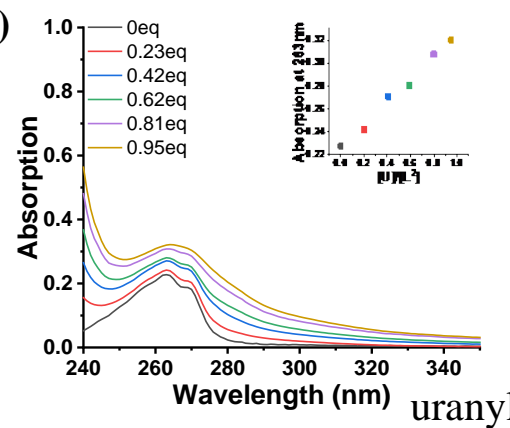

f)
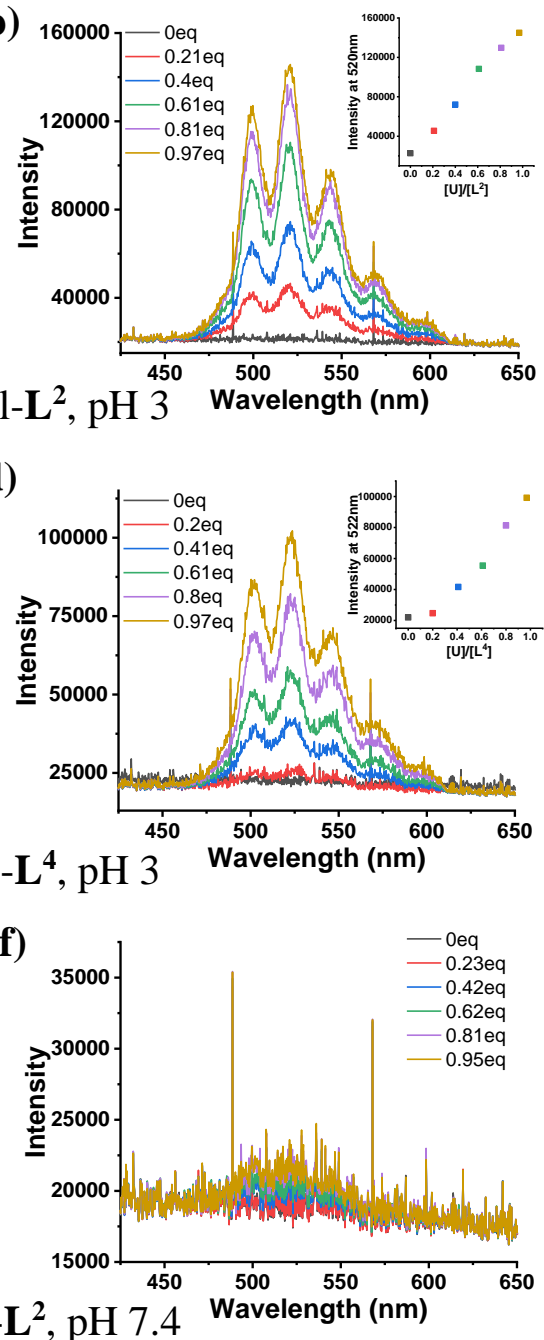

g)

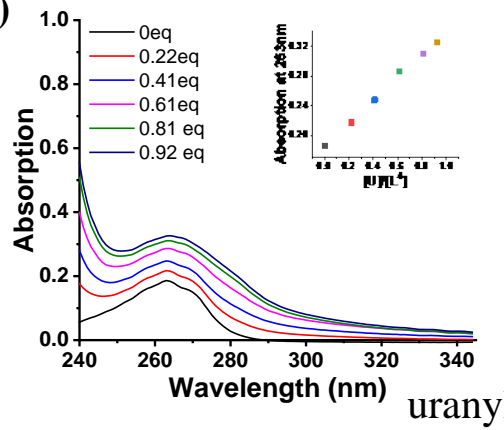

h)

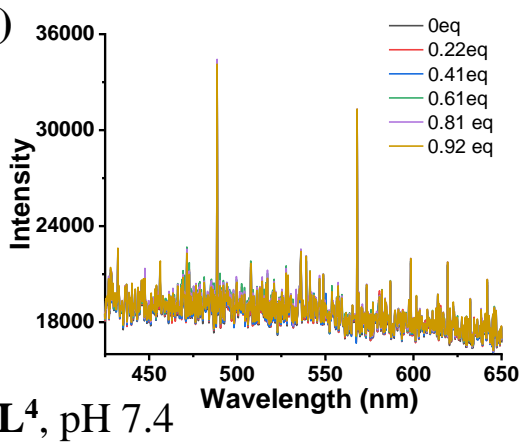


Figure 4. UV-Vis absorption and TRLFS titration experiments. Solutions of $\mathbf{L}^{2}$ (a,b,e and f) or $\mathbf{L}^{4}$ (c,d,g or h) at $5 \times 10^{-5} \mathrm{M}$ in $0.1 \mathrm{M} \mathrm{NaCl}$ were titrated by increasing amount of $\mathrm{UO}_{2}{ }^{2+}$ at acidic (pH = 3.0, a to d) and neutral ( $\mathrm{pH}=7.4$, e to f) $\mathrm{pH}$ and their UV-Vis absorption spectra (a,c,e and g) or TRLFS spectra ( $\lambda_{\text {exc }}=430 \mathrm{~nm}, \mathrm{~b}, \mathrm{~d}, \mathrm{f}$ and $\mathrm{h}$ ) were recorded. Insets represent the evolutions of the optical density for the absorption bands of the free ligands (a,c,d and g) or of the emission intensity at $522 \mathrm{vm}$ (b and d).

\section{|Thermodynamics study.}

Due to the difficult of degradation and precipitation in $0.1 \mathrm{M} \mathrm{NaClO}_{4}$ solution of uranyl- $\mathbf{L}^{2}$ complex and uranyl- $\mathbf{L}^{4}$ complex at acidic $\mathrm{pH}$, the determination of the conditional stability constant for the complexes, Kcond, could only be determined at $\mathrm{pH} 7.4$ by a competition experiment with Sulfochlorophenol S (SCP) ligand. ${ }^{32} \mathbf{L}^{2}, \mathbf{L}^{3}$ and $\mathbf{L}^{4}$ were used to investigate the affinity difference according to the phosphonate moiety and steric effect.

a)

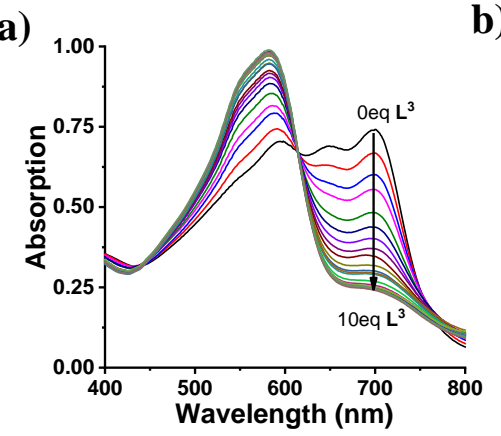

b) $\cong$

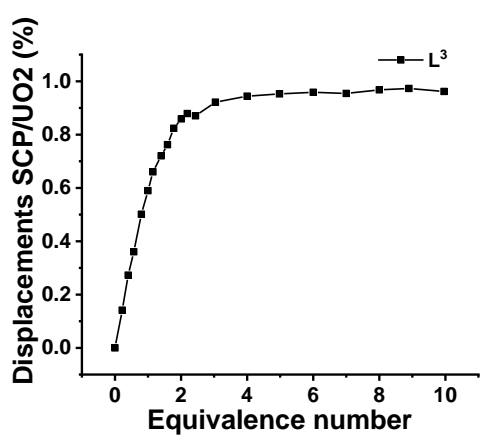

Figure 7. (a) Competition displacement titration of uranyl-SCP complex by $\mathbf{L}^{3}$ and (b)

Displacements (\%) of the SCP/ $\mathrm{UO}_{2}{ }^{2+}$ complex supposing that the complex competitive ligand/ $\mathrm{UO}_{2}{ }^{2+}$ is $1: 1$. $[\mathbf{S C P}]=[\mathrm{U}]=4 \mathrm{e}-5 \mathrm{M},\left[\mathbf{L}^{3}\right]=0-8 \mathrm{E}-4 \mathrm{M}$, HEPES buffer $=12.5 \mathrm{mmol},\left[\mathrm{Bu}_{4} \mathrm{~N}^{+} \mathrm{Cl}^{-}\right]$

Commenté [C13]: Would you have the values above one equivalent. Normally, we should reach a plateau after $1 \mathrm{eq}$. This is mportant to show.

Commenté [叶14R13]: I did several tests to go over 1 eq at the early stage. The ligand decomposed fast. After I didn't do similar study. If it needed I could perform the absorption titration but not the Commenté [C15]: This section would better fir after the UV-Vis TRLFS part

Commenté [ㅁ+16R15]: I add L3 due to the high affinity. I will add a part at the end to discuss the steric effect on complexation 
$=112.5 \mathrm{mmol}$

For $\mathbf{L}^{2}$, the constant is lower than 15.3 as the absorption difference was lower than $20 \%$ with 1 eq SCP..$^{32}$ The titration was performed in the range of 0 to 10 eq due to the relatively high affinity for $\mathbf{L}^{3}$ (Figure 7a). While for $\mathbf{L}^{4}$, the titration was done in the range of 0 to 20 eq. It appears that polyaminophosphonates ligands exhibits sufficient affinities with respect to uranium decorporation at physiological blood $\mathrm{pH}$ ( $\mathrm{pH}$ 7.4). Ligand complexation constants ( $\mathrm{K}_{\text {concd }}$ ) are 17.1 for $\mathbf{L}^{3}$ and 15.2 for $\mathbf{L}^{4}$ at $\mathrm{pH}$ 7.4. The corresponding $\mathrm{pUO}_{2}$ values $\left(\mathrm{pUO}_{2}=-\mathrm{Log}\left[\mathrm{UO}_{2}\right]_{\text {free, }}\right.$ for $[\mathrm{L}]=1 \mathrm{e}-4 \mathrm{M}$, $\left.\left[\mathrm{UO}_{2}\right]=1 \mathrm{E}-3 \mathbf{M}\right)$ of free uranyl ion are 17.4 for $\mathbf{L}^{3}$ and 15.6 for $\mathbf{L}^{4}$ at $\mathrm{pH}$ 7.4.

\section{DFT calculations and EXAFS studies.}

Prior experiments of UV-vis absorption spectroscopy and TRLFS showed that at $\mathrm{pH} 3$ and $\mathrm{pH} 7.4$ the 1:1 uranyl ligand complexes are different and predominant at an equimolar amounts. The changes in fluorescence property and complexes absorption bands at these two pHs suggest a change in the coordination of uranyl. The structures and the bond characteristics of the complexes between ligand and uranyl were then first studied by carrying out DFT calculations. Different models of uranyl-ligand complex were built and calculated. The geometries were fully refined by employing the relativistic effective core potentials (RECP) at the B3LYP level, and the solvation effects were introduced using a polarized continuum model (PCM). According to our calculations and fittings, two models (Figure 5) were defined as the possible geometry for uranyl-ligand complex at two pHs, 3 and 7.4. The ligand provides a symmetrical coordination of the uranyl ion

Commenté [C17]: Did you take into account the protonation or did you fix the protonation state? These details should be added. Commenté [叶18R17]: Yes, at pH 3 there are one proton on each phosphonate group while 0 at pH 7.4 Commenté [叶19R17]: due to the symmetrical structure of two ligands. As expected, the average bond lengths of the uranyl-ligand complexes at acidic condition (Supplementary Table 1) increase in the following 
order: $\mathrm{U}-\mathrm{O}_{\mathrm{yl}}>\mathrm{U}-\mathrm{O}_{\mathrm{P}}>\mathrm{U}-\mathrm{N}_{\mathrm{pyr}}>\mathrm{U}-\mathrm{N}_{\text {amine. }}$. These theoretical results are in agreement with the other results of the literature. ${ }^{33}$ At neutral $\mathrm{pH}$, an $\mathrm{OH}^{-}$group is present in the equatorial plane of the uranyl ion, resulting in binding lengths that follow the order $\mathrm{U}-\mathrm{O}_{\mathrm{yl}}>\mathrm{U}-\mathrm{O}_{\mathrm{P}}>\mathrm{U}-\mathrm{O}_{\mathrm{OH}}>\mathrm{U}-\mathrm{N}_{\mathrm{pyr}}>\mathrm{U}-\mathrm{N}_{\mathrm{amine}}$ (Supplementary Table 1). Since the $\mathrm{OH}^{-}$ion is much closer to the metal, an increase in the $\mathrm{U}-\mathrm{O}_{\mathrm{yl}}$ and $\mathrm{U}-\mathrm{O}_{\mathrm{p}}$ distances is observed in the uranyl- $\mathbf{L}^{2}-\mathrm{OH}$ complex compare to the uranyl- $\mathbf{L}^{2}$ complex at $\mathrm{pH}$ 3, indicating a weakening of the complexation between the ligands and uranyl due to the very strong bond existing between $\mathrm{OH}$ and the metal center. The distortion smaller distortion of the pyridine group might explain partly the differences observed in the absorption band of the previous absorption spectroscopy study. These calculated structures were used as an input for the fitting of the EXAFS experiments and the distances were compared to the experimental results.

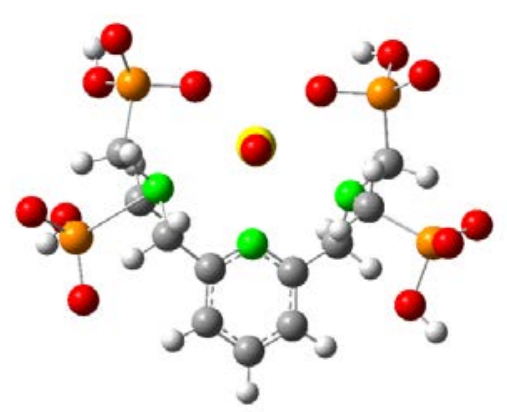

$\mathrm{UO}_{2}{ }^{2+}-\mathbf{L}^{2}$ at $\mathrm{pH}=3$

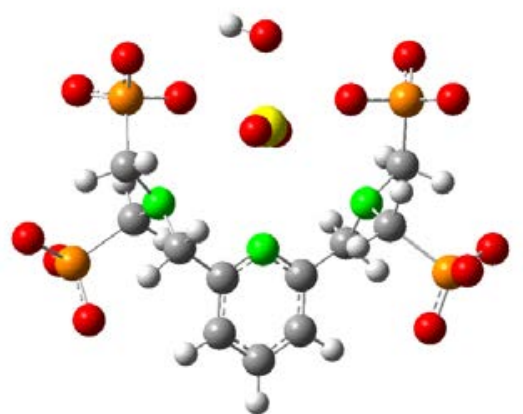

$\mathrm{UO}_{2}{ }^{2+}-\mathbf{L}^{2}-\mathrm{OH}$ at $\mathrm{pH}=7.4$

Figure 5. Theoretical models optimized by DFT and electronic density of $\mathbf{L}^{2}$ interaction sites with uranyl at pH 3 and 7.4 (Oxygen: red, carbon: blue, nitrogen: light green, uranium: yellow).

Since the presence of a single species is imperative for obtaining significant results, the EXAFS data were therefore collected at these two $\mathrm{pHs}$ of interest. The purpose of these experiments is to determine the composition of the coordination sphere of uranyl in these two conditions and thus to 
evaluate the impact of the hydroxo group coordinated to the uranyl on the complexation of the ligand.
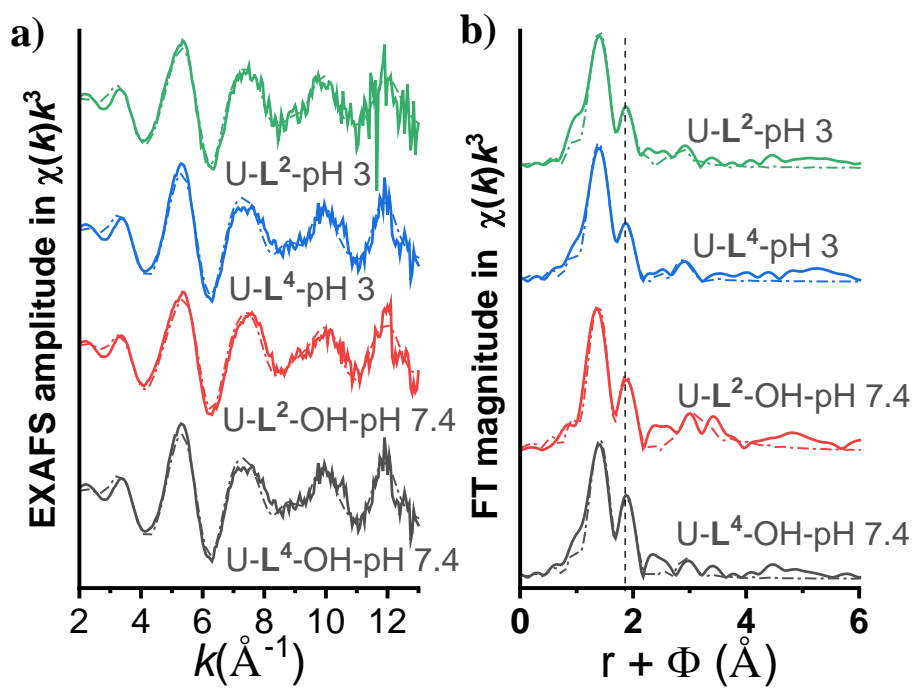

Figure 6. (a) L III edge $\mathrm{k}^{3}$-weighted EXAFS spectra and (b) the corresponding Fourier transforms of the uranyl- $\mathbf{L}^{2}$ complex and uranyl- $\mathbf{L}^{4}$ complex formed at $\mathrm{pH} 3$ and 7.4. The experimental spectra are given in line and the fits are given in dashed lines.

The splitting peak of first shell (0.5-2.2 $\AA$ ) for both ligands at pH 3 (upper traces) were similar, which indicated similar uranyl coordination (Figure 6b). However, the identical splitting peak of first shell (0.5-2.2 $\AA$ ) for both ligands at $\mathrm{pH} 7.4$ (lower traces) were more obvious. The distinct peak at the dotted line (Figure 6b) showed the different uranyl binding sites at two pHs, which was comparable with the previous results.

During the adjustment procedure, the triple diffusion paths relating to the two axial oxygens of Commenté [C23]: Not clear Commenté [叶24R23]: I made changes the uranyl was taken into account. The U-P single scattering pathway and U-P-Oax multiple scattering pathway were also necessary to perform the fit of the experimental data. 
A Hanning adjustment window in $\mathrm{k}_{3}(2 ; 12.9)$ was used and the adjustment of spectra was in $\mathrm{R}$ $(1 ; 5)$. Adjustment parameters such as passive electron reduction factor $\left(\mathrm{S}_{0}{ }^{2}\right)$ and $\Delta \mathrm{E}_{0}$ are given for each experiment. The adjustment factor $\mathrm{R}(\mathrm{r})$ and the reduced quality factor $\left(\chi^{2} \mathrm{i} \ln \right)$ are both provided as an indicator of the quality of the fit.

Taking into consideration the number of paths and the geometric constraints, the floating parameters number is 12 for the experiment $\mathrm{pH}$ 3. The fits of uranyl-ligand with $1 \mathrm{H}_{2} \mathrm{O}$ cannot converge. Fits of uranyl-ligand without $\mathrm{H}_{2} \mathrm{O}$ are the best obtained. All the results of the adjustments are summarized in Table 2. The EXAFS $\mathrm{k}_{3}$ spectra and their corresponding Fourier transforms are shown in Figure 6.

\section{Uranyl-ligand study at pH 3}

The fitting result of uranyl- $\mathrm{L}^{4}$ complex at $\mathrm{pH} 3$ is not so good. This test was performed twice. There was a bubble and precipitation which formed during the sample measurement for the first time. And the U LiII edge k3-weighted EXAFS spectra showed a little difference. For this reason, a fast scan was implementing by decreasing the accuracy and changed the position of sample to have a better reproducibility. For the uranyl- $\mathbf{L}^{2}$ complex, the fitting result is rather good.

Similar EXAFS spectra were obtained with the uranyl- $\mathbf{L}^{2}$ complex and uranyl- $\mathbf{L}^{4}$ complex at $\mathrm{pH}$ 3, which is a good indication that a unique uranyl binding site is probed under the experimental conditions used for EXAFS.

The Fourier transforms (FT) represents a pseudo-radial distribution function of the uranium nearneighbor environment. The peaks appear at lower $\mathrm{R}$ values relative to the true near-neighbor distances as a result of the EXAFS phase shift, which is different for each neighboring atom ( $\varphi$ $=0.2$ to $0.5 \AA$ ). 
Considering that the coordination of the ligand induces an axial symmetry around the $\mathrm{N}_{\text {Pyr }}-\mathrm{U}$ bond, the results show that $\mathrm{U}(\mathrm{VI})$ is coordinated by two $\mathrm{O}_{\mathrm{yl}}$ atoms at 1.80 and $1.79 \AA$, respectively for $\mathbf{L}_{2}$ and $\mathbf{L}_{4}$, two $\mathrm{O}_{\text {ph }}$ at 2.32 and $2.30 \AA$, one $\mathrm{N}_{\text {pyr }}$ at 2.50 and $2.44 \AA$ and two $\mathrm{N}_{\text {amine }}$ at 2.85 and $2.85 \AA$. The distance between $\mathrm{U}$ and $\mathrm{O}_{\mathrm{yl}}$ is typical for the uranyl ion. ${ }^{34}$ The $\mathrm{U}-\mathrm{O}_{\mathrm{ph}}$ bond length is within the range of previously reported values for the oxygen atom of phosphonate groups bound to uranyl in a monodentate fashion. ${ }^{35,36}$ These three types of atoms at equatorial plane thus could correspond to the presence of monodentate phosphonate groups and interaction with the pyridine group as deduced from UV-Vis absorption data and TRLFS data. The best fit was obtained with a coordination number of two for the $\mathrm{U}-\mathrm{O}_{\mathrm{ph}}$ bond, one for $\mathrm{N}_{\mathrm{pyr}}$ and two for $\mathrm{U}-\mathrm{N}_{\text {amine }}$ bond, which is in accordance with the presence of two monodentate binding of the phosphonate.

The other FT components were fitted with phosphors shell P at 3.69 and $3.69 \AA$ and multiple scattering with U-P-O $\mathrm{O}_{\mathrm{yl}}$ at 4.59 and $4.61 \AA$. The U-P distance of $3.69 \AA$ is consistent with a monodentate phosphonate coordination in meta-autunite. ${ }^{37}$

EXAFS data collected for the uranyl- $\mathbf{L}^{2}$ complex and uranyl- $\mathbf{L}^{4}$ complex at $\mathrm{pH} 3$ are consistent with a uranyl fivefold coordination at equatorial plane involving two monodentate phosphonate groups, one nitrogen atom from pyridine group and two nitrogen atoms from the amine parts. These experimental data are in line with UV-vis absorption and TRLFS data pointing to the absence of a water molecule at $\mathrm{pH}$ 3, (Figure 5) in accordance with the DFT simulations. The shape of the first shell of uranyl- $\mathbf{L}^{2}$ complex at $\mathrm{pH} 3$ is slightly larger than that of the uranyl- $\mathbf{L}^{4}$ complex, especially for the U-N bonds (Table 2). This might be attributed to smaller steric constraints brought by the two benzyl groups or to electrostatic repulsion arising from the supplementary negative charges of the additional phosphonate groups of $\mathbf{L}^{2}$ which are monodeprotonated at this $\mathrm{pH}$. 


\begin{tabular}{|c|c|c|c|}
\hline & $N$ & $\sigma^{2}\left(\AA^{2}\right)$ & $\mathrm{R}(\AA)$ \\
\hline \multicolumn{2}{|c|}{ uranyl-L $\mathbf{L}^{2}$ complex, $\mathrm{pH} 3$} & \multicolumn{2}{|c|}{$\mathrm{S}_{0}^{2}=1.27 ; \Delta \mathrm{E}_{0}=5.67 \mathrm{eV} . \mathrm{R}=0.02$} \\
\hline $\mathrm{U}-\mathrm{O}_{\mathrm{yl}}$ & 2 & 0.0039 & 1.81 \\
\hline $\mathrm{U}-\mathrm{O}_{\mathrm{p}}$ & 2 & 0.0040 & 2.32 \\
\hline U-N $\mathrm{N}_{\text {pyr }}$ & 1 & 0.0029 & 2.50 \\
\hline U-Namine & 2 & 0.0272 & 2.83 \\
\hline U-P & 2 & 0.0195 & 3.69 \\
\hline $\mathrm{U}-\mathrm{P}-\mathrm{O}_{\mathrm{ax}}$ & 4 & 0.0079 & 4.59 \\
\hline \multicolumn{2}{|c|}{ uranyl-L ${ }^{4}$ complex, pH 3} & \multicolumn{2}{|c|}{$\mathrm{S}_{0}^{2}=1.19 ; \Delta \mathrm{E}_{0}=6.50 \mathrm{eV} \cdot \mathrm{R}=0.03$} \\
\hline $\mathrm{U}-\mathrm{O}_{\mathrm{yl}}$ & 2 & 0.0037 & 1.80 \\
\hline $\mathrm{U}-\mathrm{O}_{\mathrm{p}}$ & 2 & 0.0029 & 2.31 \\
\hline $\mathrm{U}-\mathrm{N}_{\mathrm{pyr}}$ & 1 & 0.0021 & 2.44 \\
\hline $\mathrm{U}-\mathrm{N}_{\text {amine }}$ & 2 & 0.0099 & 2.95 \\
\hline U-P & 2 & 0.0150 & 3.69 \\
\hline $\mathrm{U}-\mathrm{P}-\mathrm{O}_{\mathrm{ax}}$ & 4 & 0.0066 & 4.61 \\
\hline \multicolumn{2}{|c|}{ uranyl-L²-OH complex, pH 7.4. } & \multicolumn{2}{|c|}{$\mathrm{S}_{0}^{2}=1.22 ; \Delta \mathrm{E}_{0}=3.62 \mathrm{eV} . \mathrm{R}=0.01$} \\
\hline $\mathrm{U}-\mathrm{O}_{\mathrm{yl}}$ & 2 & 0.0040 & 1.82 \\
\hline $\mathrm{U}-\mathrm{O}_{\mathrm{p}}$ & 2 & 0.0082 & 2.28 \\
\hline $\mathrm{U}-\mathrm{O}_{\mathrm{OH}}$ & 1 & 0.0082 & 2.31 \\
\hline $\mathrm{U}-\mathrm{N}_{\mathrm{pyr}}$ & 1 & 0.0049 & 3.09 \\
\hline U-Namine & 2 & 0.0105 & 3.20 \\
\hline U-P & 1 & 0.0091 & 3.59 \\
\hline \multicolumn{2}{|c|}{ uranyl-L4-OH complex, pH 7.4. } & \multicolumn{2}{|c|}{$\mathrm{S}_{0}^{2}=1.20 ; \Delta \mathrm{E}_{0}=7.20 \mathrm{eV} . \mathrm{R}=0.01$} \\
\hline $\mathrm{U}-\mathrm{O}_{\mathrm{yl}}$ & 2 & 0.0028 & 1.81 \\
\hline $\mathrm{U}-\mathrm{O}_{\mathrm{p}}$ & 2 & 0.0070 & 2.37 \\
\hline $\mathrm{U}-\mathrm{O}_{\mathrm{OH}}$ & 1 & 0.0070 & 2.40 \\
\hline $\mathrm{U}-\mathrm{N}_{\mathrm{pyr}}$ & 1 & 0.0084 & 3.03 \\
\hline $\mathrm{U}-\mathrm{N}_{\text {amine }}$ & 1 & 0.0093 & 3.39 \\
\hline U-P & 1 & 0.0028 & 3.81 \\
\hline
\end{tabular}

\section{Uranyl-ligand study at pH 7.4}

The most stable adopted model at $\mathrm{pH} 7.4$ includes two axial oxygen atoms $\left(\mathrm{O}_{\mathrm{yl}}\right)$, two equatorial oxygen atoms $\left(\mathrm{O}_{\mathrm{ph}}\right)$, three equatorial nitrogen atoms $\left(\mathrm{N}_{\mathrm{pyr}}\right.$ and $\left.2 \mathrm{~N}_{\mathrm{amine}}\right)$ with or with $\mathrm{O}_{\mathrm{oH}}$. The $\mathrm{O}_{\mathrm{ph}}$ atom represents the oxygen atom of the monodente phosphonate group; $\mathrm{O}_{\mathrm{OH}}$ represents the oxygen atom of the hydroxide. $\mathrm{N}_{\mathrm{pyr}}$ atom represents the nitrogen atom of pyridine group; $\mathrm{N}_{\mathrm{amine}}$ represents 
the nitrogen atom from amine units. An additional layer representing the phosphors atoms associated to the above-mentioned phosphonate oxygen atoms has also been taken into account. The assignment is slightly different. $\mathrm{O}_{\mathrm{OH}}$ represents the hydroxide present in the coordination sphere; the oxygen of the hydroxide was grouped together with the oxygen of the phosphonate oxygen in the same layer because they are at roughly the same distance from the metal.

The EXAFS data could be fitted with both models with and without hydroxide. However, considering the results of UV-Vis and TRLFS studies, the coordination at the two pHs are not the same. Thus, the model of uranyl-ligand with hydroxide was used at pH 7.4. The model of uranyl$\mathbf{L}^{2}$ complex obtained from the DFT calculations are used in the fitting of uranyl- $\mathbf{L}^{2}$ complex.

Taking into consideration the number of paths and the geometric constraints, the floating parameters number is 12 for the experiment $\mathrm{pH}$ 7.4. All the results of the adjustments are summarized in Table 2. The EXAFS $\mathrm{k}_{3}$ spectra and their corresponding Fourier transforms are shown in Figure 6.

Both fitting results of uranyl-ligand complex are good. This test was performed twice. There is an uranium redox reaction happened during the sample measurement for the first time for uranyl$\mathbf{L}^{2}$ complex at $\mathrm{pH}$ 7.4. The charge of uranium was decreased from VI to IV. For this reason, a fast scan was implementing by decreasing the accuracy and changed the position of sample to have a better reproducibility.

Similar EXAFS spectra were obtained with the uranyl- $\mathbf{L}^{2}$ complex and uranyl- $\mathbf{L}^{4}$ complex at $\mathrm{pH}$ 7.4, which is a good indication that a unique uranyl binding site is probed under the experimental conditions used for EXAFS.

For uranyl complexes at $\mathrm{pH} 7.4$, the fit shows that $\mathrm{U}(\mathrm{VI})$ has two $\mathrm{O}_{\mathrm{yl}}$ atoms at a distance of 1.78 and $1.81 \AA$, respectively for $\mathbf{L}^{2}$ and $\mathbf{L}^{4}$, two $\mathrm{O}_{\mathrm{ph}}$ at 2.28 and $2.37 \AA$, one $\mathrm{O}_{\text {oн }}$ at 2.31 and 2.40, one 
$\mathrm{N}_{\text {pyr }}$ at 2.93 and $3.03 \AA$ and two $\mathrm{N}_{\text {amine }}$ at 3.24 and $3.38 \AA$. The distance between $\mathrm{U}$ and $\mathrm{O}_{\mathrm{yl}}$ is typical for a uranyl ion. ${ }^{34}$ The $\mathrm{U}-\mathrm{O}_{\mathrm{ph}}$ bond length is within the range of previously reported values for the oxygen atom of phosphonate groups bound to uranyl in a monodentate fashion. ${ }^{35,36}$ These five types of atoms at equatorial plane thus could correspond to the presence of monodentate phosphonate groups and interaction with the pyridine group as deduced from the FT-IR data and UV-vis absorption data. The best fit was obtained for a coordination number of six in the equatorial plane; two for the $\mathrm{U}-\mathrm{O}_{\mathrm{ph}}$ bond, one for $\mathrm{U}-\mathrm{O}_{\mathrm{OH}}$ bond, one for $\mathrm{U}-\mathrm{N}_{\mathrm{pyr}}$ bond and two for $\mathrm{U}-\mathrm{N}_{\mathrm{amine}}$ bond, in accordance with the presence of two monodentate binding phosphonate.

The other FT components were fitted with phosphors shell P at 3.59 and 3.81 A. The U-P distance is consistent with a monodentate phosphonate coordination in meta-autunite. ${ }^{37}$

EXAFS data collected for the uranyl- $\mathbf{L}^{2}$ complex and uranyl- $\mathbf{L}^{4}$ complex at $\mathrm{pH} 7.4$ are consistent. These experimental data are in line with UV-vis absorption data, TRLFS data and FTIR data with model of uranyl-ligand with $\mathrm{OH}$ at $\mathrm{pH} 7.4$ (Figure 5) coming from the DFT simulations. As observed at $\mathrm{pH}$ 3.0, the uranyl- $\mathrm{L}^{4}$ complex at $\mathrm{pH} 7.4$ presents longer bonds than In the case in uranyl- $\mathbf{L}^{2}$ complex. The difference of $\mathrm{U}-\mathrm{O}_{\mathrm{OH}}$ bond for two uranyl-ligand complexes might result in the larger negative charge for the complex of $\mathbf{L}^{2}$ at neutral $\mathrm{pH}$.

The uranyl ion is moving forward from the pyridine group from $\mathrm{pH} 3$ to $\mathrm{pH} 7.4$ due to the increasing of hydroxide concentration. The attraction of oxygen atom from hydroxide strongly altered the uranyl coordination, five-fold coordination at pH 3 to six-fold coordination at pH 7.4.

\section{In vitro Competition study of chelating agent with endogeneous cations}

Because most study on actinide biokinetics focuses on blood, three cations, $\mathrm{Ca}^{2+}, \mathrm{Mg}^{2+}$ and $\mathrm{Fe}^{3+}, 38$ were chosen for a competition study with endogeneous cations. Owing to the non- 
fluorescence uranyl-ligand complex at neutral $\mathrm{pH}$, the competition was then investigated using TRLFS and UV-vis absorption experiments consisting in addition of the competing metal cation $\left(\mathrm{M}^{+}\right)$in the presence of the uranyl- $\mathbf{L}^{4}$ complex. An increase of the fluorescence signal is expected if those metals form a new complex with $\mathbf{L}^{4}$. Competing metal cations, $\mathrm{Ca}^{2+}, \mathrm{Mg}^{2+}$ and $\mathrm{Fe}^{3+}$, have been added to the solution of the 1:1 uranyl- $\mathbf{L}^{4}$ complex at $\mathrm{pH}$ 7.4. Unfortunately, formation of a precipitate was observed with $\mathrm{Fe}^{3+}$, restricting the study to $\mathrm{Ca}^{2+}$ and $\mathrm{Mg}^{2+}$. The $1: 1$ uranyl- $\mathbf{L}^{4}$ complex concentration was set to $5 \times 10^{-5} \mathrm{M}$. The concentrations of $\mathrm{Ca}^{2+}$ and $\mathrm{Mg}^{2+}$ in blood are $1.4 \times 10^{-3} \mathrm{M}$ and $5.6 \times 10^{-4} \mathrm{M}$, corresponding respectively to $\mathrm{ca} 25$ and 11.2 times the concentration of uranyl- $\mathbf{L}^{4}$ complex. The data revealed that the uranyl-ligand $\mathbf{L}^{4}$ complex presents a good stability even in the presence of excess of $\mathrm{Ca}^{2+}$ and $\mathrm{Mg}^{2+}$ at the concentration of blood (Supplementary Figure 5).

In order to verify the potential implementation in chelation therapy, Calmodulin (CaM), a metal protein which plays an important role in extracellular stimulus, and which has already been studied in details, ${ }^{28,39-41}$ was used for a simulation test.

According to the structure of CaM, 4 calciums occupy different sites of CaM. ${ }^{42-44}$ Due to the affinity difference of the 4 sites of CaM, four equivalents of uranyl ion were added to compete with the calcium ions of each sites. Considering the hydrolysis of uranyl and the stability constants of the uranyl-calmodulin complexes, $\mathrm{pH} 5.5$ was chosen for the chelation study. At this $\mathrm{pH}$, the predominant species are: $\mathrm{Ca}_{3} \mathrm{UO}_{2} \mathrm{CaM}(\mathrm{OH}), \mathrm{Ca}_{3} \mathrm{UO}_{2} \mathrm{CaM}$ and $\mathrm{UO}_{2}(\mathrm{OH})_{2} \cdot{ }^{40,45} \mathrm{MES}$ buffer was used to maintain the $\mathrm{pH}$ during the study.

Considering its high affinity toward uranyl and the absence of fluorescence of the complex formed with uranyl, ligand $\mathbf{L}^{4}$ was chosen for the study consisting of addition of $\mathbf{L}^{4}$ to the CaMuranyl solution. 


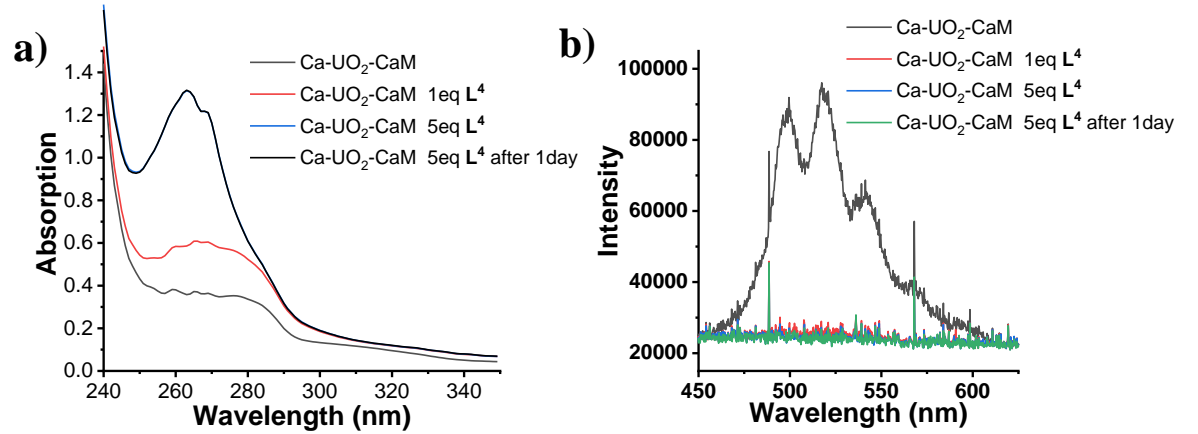

Figure 8. Chelation study of $\mathbf{L}^{4}$ towards Ca- $\mathrm{UO}_{2}-\mathrm{CaM}$ complex, (a) absorption spectrum and (b) fluorescence spectrum $[\mathrm{CaM}]=[\mathrm{U}]=2.5 \times 10^{-5} \mathrm{M} ;\left[\mathrm{Ca}^{2+}\right]=2 \times 10^{-4} \mathrm{M} ;\left[\mathrm{L}^{4}\right]=0,1$ and $5 \mathrm{eq} ;\left[\mathrm{NaClO}_{4}\right]$ $=0.1 \mathrm{M} ;[\mathrm{MES}]=5 \mathrm{mmol} ; \mathrm{pH} 5.5$.

As evidenced by the fluorescence spectra (Figure 8b), a complete loss of fluorescence could be observed as soon as 10 minutes after the addition of one equivalent of $\mathbf{L}^{4}$ meaning that all the uranyl is complexed by $\mathbf{L}^{4}$. Another 4eq was added for spectra deconvolution and stability check. Both the absorption spectra and fluorescence spectra didn't change after 1day.

The difference on the absorption in UV range between the recorded $\mathrm{UO}_{2}-\mathrm{CaM}$ spectra with the two CaM spectra from deconvolution confirmed the formation of $\mathrm{UO}_{2}-\mathrm{L}^{4}$ at 1 eq and 5 eq and complete sequestering of uranyl ion from CaM (Supplementary Figure 6). Thus, the uranyl ion was wrapped by $\mathbf{L}^{4}$ which could be further excreted in urine. This result is coherent with the fluorescence measurement.

\section{Conclusion}

The synthesis of two new bis-phosphonated pyridine ligands, $\mathbf{L}^{3}$ and $\mathbf{L}^{4}$ was successfully achieved, offering a new series of potential uranyl decorporation agents.
Commenté [C32]: The blue curve is missing in figure a Commenté [0+33R32]: The blue curve is overlapping by the green one 
The different coordination behavior at $\mathrm{pH} 3$ and 7.4 of uranyl complexes with same five members ring polyaminophosphonate ligands were derived from UV-Vis absorption spectrum and TRLFS results. A combination of DFT calculation and EXAFS were implemented to define the environment of uranyl ion. At both $\mathrm{pH}$, the environments of uranyl ion consisted in the coordination of the pentadentate ligands in the equatorial plane of uranyl with coordination of two oxygen atoms from monodentate phosphonate groups, one nitrogen atom from the pyridyl group and two nitrogen atoms from the amine parts for both ligands, $\mathbf{L}^{2}$ and $\mathbf{L}^{4}$. The main difference was found in the presence of a supplementary hydroxide anion in the equatorial plane of uranyl at neutral pH.

The conditional stability constants observed for the formation of the 1:1 uranyl:ligand complexes ( $K_{\text {concd }}$ expressed in $\log K$ ) are 17.08 for $\mathbf{L}^{3}, 15.2$ for $\mathbf{L}^{4}$ at $\mathrm{pH} 7.4$ and in 13.3 to 15.3 for $\mathbf{L}^{2}$ by displacement titration method. These values are similar to other values reported in the literature Commenté [C34]: Where is it Commenté [ [ 3 35R34]: I add explanation in previous paragraph this time. such as i.e. 17 for 5 -LICAMS ${ }^{42}$ and 16.87 for 3,4,3-LI(1,2-HOPO $)^{35}$ which are the most effective uranyl chelating agents. By combining the UV-Vis absorption spectrum and TRLFS, the strong stability of uranyl- $\mathbf{L}^{4}$ complex was confirmed by competition experiments with endogeneous metal, $\mathrm{Na}^{+}, \mathrm{Ca}^{2+}$ and $\mathrm{Mg}^{2+}$, at $\mathrm{pH} 7.4$ and with completion protein, Calmodulin, at $\mathrm{pH}$ 5.5.

Therfore, the bis-phosphonated ligands have strong complexation affinities and good stability with uranyl ion at biological condition due to the well design of chelating agents. Future studies will be devoted to the in vitro behavior of the polyaminophosphonate ligand with kidney culture cells for the application.

\section{Methods}

Ligand synthesis. Solvents and starting materials were purchased from Aldrich, Acros, and Alfa Aesar and used without further purification. IR spectra were recorded on a PerkinElmer Spectrum One spectrophotometer as solid samples, and only the most significant absorption bands are given 
in $\mathrm{cm}^{-1}$. Elemental analyses and mass spectrometry analysis were carried out by the Service Commun d'Analyses of the University of Strasbourg. ${ }^{1} \mathrm{H},{ }^{13} \mathrm{C}$ and ${ }^{31} \mathrm{P}$ NMR spectra were recorded on Bruker Avance 300 and Avance 400 spectrometers operating at 300 and $400 \mathrm{MHz}$, respectively. Chemical shifts are reported in ppm, relative to residual protonated solvent as internal reference. ${ }^{43}$ Elemental analysis and monoisotopic masses were calculated with the Chemcalc software. ${ }^{44}$

2,6-Bis(bromomethyl)pyridine (1). To a solution of 2,6-pyridinedimethanol (3.36 g, $24.1 \mathrm{mmol}$ ) in $\mathrm{DMF}(20 \mathrm{~mL})$ at $0^{\circ} \mathrm{C}, \mathrm{PBr}_{3}(5.22 \mathrm{~mL}, 55.6 \mathrm{mmol})$ was added dropwise. The mixture was stirred at room temperature for $6 \mathrm{~h}$, then water was added $(300 \mathrm{~mL})$ to solubilize the formed solid. After extraction with $\mathrm{CH}_{2} \mathrm{Cl}_{2}(3 \times 100 \mathrm{~mL})$, the organic layer was dried with $\mathrm{Na}_{2} \mathrm{SO}_{4}$ and the solvent was removed in vacuo to yield a yellow solid. The crude product was purified by flash chromatography $\left(\mathrm{CH}_{2} \mathrm{Cl}_{2}\right)$ to give compound 1 as a pure white solid (5.26 g, $\left.82 \%\right) .{ }^{1} \mathrm{H} \mathrm{NMR}\left(400 \mathrm{MHz}, \mathrm{CDCl}_{3}\right): \delta$ 7.64 (t, J = 7.7 Hz, 1H), 7.31 (d, J = 7.7 Hz, 2H), 4.47 (s, 4H).

1,3,5-Tribenzylhexahydrotriazine (2). To a stirred solution of benzylamine (20.7 g, $193 \mathrm{mmol}$ ) at $0^{\circ} \mathrm{C}, 37 \%$ aqueous formaldehyde solution $(19.4 \mathrm{~mL}, 60.7 \mathrm{mmol})$ was slowly added keeping the temperature below $5^{\circ} \mathrm{C} .1 \mathrm{M}$ aqueous sodium hydroxide solution $(5 \mathrm{~mL})$ was added to the resulting precipitated gum and the mixture was submitted to an ultrasonic treatment for $1 \mathrm{~h}$ at $0^{\circ} \mathrm{C}$. Diethyl ether $(190 \mathrm{~mL})$ was added and the aqueous phase was further extracted with diethyl ether $(3 \times 50$ $\mathrm{mL}$ ). The combined organic layers were dried with $\mathrm{Na}_{2} \mathrm{SO}_{4}$ and the solvent was removed under reduced pressure to yield a colorless oil. The crude product was purified by flash chromatography (Cyclohexane/Ethyl Acetate 100/0 to 85/15). Compound 4 was obtained as a colorless oil (21.1 g, 91\%). ${ }^{1} \mathrm{H}$ NMR (300 MHz, $\left.\mathrm{CDCl}_{3}\right): \delta 7.33$ - 7.05 (m, 15H), 3.59 (s, 6H), 3.34 (s broad, $\left.5 \mathrm{H}\right)$.

Diethyl ((benzylamino)methyl)phosphonate (3). Compound 2 (4 g, $11.2 \mathrm{mmol})$ was added to diethyl phosphite $(5.1 \mathrm{~g}, 36.9 \mathrm{mmol})$, under nitrogen and the mixture was heated at $100^{\circ} \mathrm{C}$ for 16

Commenté [C36]: 5 or 6 ? Commenté [叶37R36]: The broad band is 5 . Hard to 6 Commenté [C38]: What about masses, 13C, elemental analysis? Commenté [0+39R38]: Didn't do it since it is well characterized in other paper 
h. The resulting product was purified by flash chromatography (Ethyl Acetate) to give compound 5 as an oily product (3.65 g, 79 \%). ${ }^{1} \mathrm{H}$ NMR (300 MHz, $\left.\mathrm{CDCl}_{3}\right): \delta 7.33-7.09$ (m, 5H), 4.07 (m, 4H), 3.80 (s, 2H), 2.88 (d, $\left.J_{P H}=12.6 \mathrm{~Hz}, 2 \mathrm{H}\right), 1.61$ (s broad, $\left.1 \mathrm{H}\right), 1.26(\mathrm{t}, \mathrm{J}=7.1 \mathrm{~Hz}, 6 \mathrm{H}) .{ }^{31} \mathrm{P}$ NMR (162 MHz, $\left.\mathrm{CDCl}_{3}\right): \delta 25.7$.

Tetraethyl (((pyridine-2,6diylbis(methylene))bis(benzylazanediyl))bis(methylene))bis(phosphonate) (4). Under a nitrogen atmosphere, amine 3 (1.1 g, $4.3 \mathrm{mmol})$ and freshly flame-dried $\mathrm{K}_{2} \mathrm{CO}_{3}(1.2 \mathrm{~g}, 9.1 \mathrm{mmol})$ were added to a solution of 2,6-bis(bromomethyl)pyridine 1 (600 mg, $2.26 \mathrm{mmol}$ ) in MeCN (20 mL). The mixture was heated for $16 \mathrm{~h}$ at $70^{\circ} \mathrm{C}$. After filtration, the solvent was removed in vacuo and the crude oil was purified by flash chromatography (Ethyl Acetate/MeOH 100/0 to 90/10). Compound 7 was obtained as an oily light-yellow product (1.1 g, $79 \%$ ). ${ }^{1} \mathrm{H}$ NMR (400 MHz, $\left.\mathrm{CDCl}_{3}\right): \delta 7.59$ (t, J = 7.7 Hz, 1H), 7.38 (d, J = $7.7 \mathrm{~Hz}, 2 \mathrm{H}), 7.34-7.10$ (m, 10H), 4.05 - 3.93 (qd, $J=7.2 \mathrm{~Hz}, J=$ $7.2 \mathrm{~Hz}, 8 \mathrm{H}), 3.85$ (s, 4H), 3.73 (s, 4H), 2.88 (d, $J=10.6 \mathrm{~Hz}, 4 \mathrm{H}), 1.21$ (t, $J=7.1 \mathrm{~Hz}, 12 \mathrm{H}) .{ }^{13} \mathrm{C}$ NMR (100 MHz, $\left.\mathrm{CDCl}_{3}\right): \delta$ 158.6, 138.6, 137.0, 129.2, 128.4, 127.3, 121.5, 61.9 (d, J = $\left.6.7 \mathrm{~Hz}\right)$, 61.2 (d, J = 8.3 Hz), 59.8 (d, J = 9.0 Hz), 49.1 (d, J = $161.5 \mathrm{~Hz}), 16.6$ (d, J = 6.0 Hz). ${ }^{31} \mathrm{P}$ NMR (162 MHz, $\left.\mathrm{CDCl}_{3}\right): \delta$ 25.4. (Supplementary Figure 1a) ((((6((benzyl((diethoxyphosphoryl)methyl)amino)methyl)pyridin-2-yl)methyl)amino)methyl) diphosphonic acid $\mathbf{L}^{3}$. The $\mathbf{L}^{3}$ ligandwas isolated as a byproduct of the synthesis of $\mathbf{L}^{\mathbf{4}}(0.15 \mathrm{~g}, 13$ \%). 1H NMR (400 MHz, $\left.\mathrm{D}_{2} \mathrm{O}\right): \delta 7.64$ (t, J = 7.8 Hz, 1H), 7.33 (d, J = 7.7 Hz, 1H), 7.25 - 7.04 (m, 6H), 3.78 (d, J = 21.9 Hz, 4H), 3.63 (s, 2H), 2.58 (d, J = 11.6 Hz, 2H), 2.51 (d, J = $12.7 \mathrm{~Hz}, 2 \mathrm{H}) .{ }^{13} \mathrm{C}$ NMR (101 MHz, D $2 \mathrm{O}) \delta 163.10$ (s), 158.72 (s), 138.56 (s), 138.56 (s), 129.86 (s), 128.18 (s), 127.08 (s), 122.89 (s), 120.84 (s), 60.28 (d), 59.24 (d, J = 8.2 Hz), 55.19 (d, J = 12.8 Hz), 54.34 (d, $\mathrm{J}=140.4 \mathrm{~Hz}), 47.70(\mathrm{~d}, \mathrm{~J}=137.0 \mathrm{~Hz}) .{ }^{31} \mathrm{P}$ NMR $\left(162 \mathrm{MHz}, \mathrm{D}_{2} \mathrm{O}\right) \delta 16.39,15.91$. (Supplementary 
Figure 1b) $\mathrm{ESI}^{+} / \mathrm{MS}\left(\mathrm{D}_{2} \mathrm{O}\right): \mathrm{m} / \mathrm{z}=416.1([\mathrm{M}+\mathrm{H}]+, 100 \%) ; \mathrm{m} / \mathrm{z}=831.2\left([2 \mathrm{M}+\mathrm{H}]^{+}, 15\right.$ \%).(Supplementary Figure 7a) Calc. for $\mathrm{C}_{16} \mathrm{H}_{23} \mathrm{~N}_{3} \mathrm{O}_{6} \mathrm{P}_{2} \bullet$ TFA: C, 41.6; H, 5.77; N, 8.66; Found: C, 40.9; H, 4.57; N,

7.94.

(((pyridine-2,6-diylbis(methylene))bis(benzylazanediyl))bis(methylene))diphosphonic acid $\mathbf{L}^{4}$. Compound 4 (1.7 g, $2.79 \mathrm{mmol})$ was dissolved in $6 \mathrm{M} \mathrm{HCl}(36.5 \mathrm{~mL})$ and the mixture was heated at reflux for $16 \mathrm{~h}$. The solvent was removed under reduced pressure. After completion of the reaction, the mixture was evaporated to dryness, and the crude product was purified by flash chromatography with a C18 reverse phase column (eluent system $\mathrm{H}_{2} \mathrm{O} / \mathrm{ACN} / \mathrm{TFA}$ 100/0/0.1\% to 70/30/0.1\%), to give ligand $\mathbf{L}^{4}(0.74$ g, $52 \%) .{ }^{1} \mathrm{H}$ NMR (400 MHz, $\left.\mathrm{D}_{2} \mathrm{O}\right): \delta 7.47$ (t, $J=7.8 \mathrm{~Hz}$, 1H), 7.14 (d, $J=6.7 \mathrm{~Hz}, 4 \mathrm{H}), 7.07$ - $6.72(\mathrm{~m}, 8 \mathrm{H}), 4.73$ (s, 4H), 4.30 (s, 4H), 3.17 (d, J = $12.4 \mathrm{~Hz}$, 4H). ${ }^{13} \mathrm{C}$ NMR (126 MHz, D $\left.{ }_{2} \mathrm{O}\right): \delta 158.40$ (s), 138.78 (s), 137.90 (s), 129.96 (s), 128.30 (s), 127.17 (s), 122.78 (s), 60.62 (d, J = 5.5 Hz), 59.42 (d, J = $8.7 \mathrm{~Hz}), 53.52$ (t, J = $190.4 \mathrm{~Hz}) .{ }^{31} \mathrm{P}$ NMR (162 $\left.\mathrm{MHz}, \mathrm{D}_{2} \mathrm{O}\right): \delta$ 7.64. $\mathrm{ESI}^{+} / \mathrm{MS}\left(\mathrm{D}_{2} \mathrm{O}\right): \mathrm{m} / \mathrm{z}=506.2\left([\mathrm{M}+\mathrm{H}]^{+}, 100 \%\right), \mathrm{m} / \mathrm{z}=1011.3\left([2 \mathrm{M}+\mathrm{H}]^{+}, 23\right.$

Commenté [C40]: Or 2? Commenté [C41]: Or 10?

\section{Physicochemical Studies.}

Materials. Distilled water was purified by passing through a mixed bed of ion exchange (Bioblock Scientific R3-83002, M3-83006) and activated carbon (Bioblock Scientific ORC-83005). All the stock solutions were prepared by weighing solid products using an AG 245 Mettler Toledo analytical balance (precision $0.01 \mathrm{mg})$. Sodium hydroxide $(\mathrm{NaOH})$ and hydrochloric acid $(\mathrm{HCl})$ 
were used to adjust $\mathrm{pH}$ during titrations. The ionic strength of all the solutions was fixed to $0.1 \mathrm{M}$ with sodium perchloride (Merck, p.a., $\mathrm{NaClO}_{4}$ ). All the experiments described were repeated at least three times.

UV-Visible. UV-visible spectrophotometric analysis were performed on an Agilent Technologies Cary 60 UV-vis apparatus equipped with a deuterium lamp and a tungsten lamp. The measurements were carried out in scanning mode from 200 to $800 \mathrm{~nm}$ (scanning speed of $3.3 \mathrm{~nm} / \mathrm{s}$ ).

Displacement titration $0.0125 \mathrm{M}$ buffers were prepared by dissolving the acid form of buffer 12.5 mmol (MES for $\mathrm{pH}=5.5$, HEPES for $\mathrm{pH}=7.4$ and CHESS for $\mathrm{pH}=9.0$ ) and $112.5 \mathrm{mmol}$ of $\mathrm{n}$ $\mathrm{Bu}_{4} \mathrm{Cl}$ in $1 \mathrm{~L}$ of Millipore water. The $\mathrm{pH}$ was adjusted to the $\mathrm{pH}$ meter by addition of $\mathrm{nBu}_{4} \mathrm{~N}^{+} \mathrm{OH}^{-}-$ $30 \mathrm{H}_{2} \mathrm{O} .100 \mu \mathrm{M}$ Sulfochlorophenol S (SCP) Solution: $6.25 \mathrm{~mL}$ of $4 \mathrm{mM}$ SCP stock solution were mixed in $244 \mathrm{~mL}$ of appropriate buffer. SCP- $\mathrm{UO}_{2}{ }^{2+}$ solution at $100 \mu \mathrm{M}$ : $6.25 \mathrm{~mL}$ of stock solution of SCP at $4 \mathrm{mM}$ were mixed in $243 \mathrm{~mL}$ of water and $1.2 \mathrm{~mL}$ of uranyl stock solution (20mM) were added. Both stock solutions were stored for 1h before use. The ligand solutions were prepared by diluting the stock solutions of $2 \mathrm{mM}$ ligands with water to obtain a final concentration of $400 \mu \mathrm{M}$. In each $1 \mathrm{~mL}$ centrifugation tube, $100 \mu \mathrm{l}$ of SCP-UO $\mathrm{U}_{2}$ solution $(40 \mu \mathrm{M})$ in HEPES buffer were added, different volume of each ligand solution ( $5 \mathrm{mM}$ ) were added to reach 0 to 10 eq of ligand concentration. Samples of SCP solution, $\mathrm{SCP}-\mathrm{UO}_{2}$ solution and ligand solution at the same concentration are also prepared as reference. The tubes were stored in the dark at room temperature for 36 hours for equilibration. The samples were read by Cary $60 \mathrm{UV}$-vis apparatus. Measurements were made at $690 \mathrm{~nm}$ for $\mathrm{pH}=7.4$. 
Using the Hyss speciation program, we calculated the complexation conditional constants assuming that the complex formed L (tested) -uranyl has the stoichiometry 1: 1 in our experimental conditions. $^{35}$

TRLFS The experiments were conducted using a laser excitation source Nd:YAG (7 ns pulse at a frequency of $10 \mathrm{~Hz}$ with energy of $2 \mathrm{~mJ}$ ) of the company Continuum coupled to an Optical Parametric Oscillator (OPO, Panther, Continuum). Detection is performed using a Spectra-Pro-300 monochromator (Acton Research Corporation) coupled to a CCD camera (Princeton Instruments). The beam passes through a quartz cuvette containing the solution to be analyzed before reaching the detector. A lens and mirror system focus the fluorescence beam onto the input slot of the spectrophotometer that selects the wavelength range to be observed. The CCD camera makes it possible to adjust the various measurement parameters for the resolution in time: the delay, the gate width, the integration time and the number of spectra. Spectra are recorded using WINSPEC software (Princeton Instruments). The excitation wavelength chosen for the measurement of uranium is $430 \mathrm{~nm}$. The error on the intensity of the fluorescence is less than $5 \%$ and the resolution greater than $0.2 \mathrm{~nm}$.

DFT Computational Details. All the structures were optimized by using the DFT approach as implemented in the Gaussian09 package. ${ }^{45}$ Calculations were performed using the hybrid B3LYP functional. ${ }^{46}$ MWB60 Stuttgart relativistic effective core potentials ${ }^{47}$ were used to describe the uranium and neptunium atoms, MWB2 for the oxygen, nitrogen, and carbon atoms, and the 6-31G basis set was used for hydrogen. To consider the part of the solvent effect, solvation was introduced using a dielectric continuum model of permittivity $\varepsilon_{0}=80$. The conductor-like polarizable 
continuum model (CPCM) ${ }^{48}$ implemented in Gaussian09 was used as well.

EXAFS. EXAFS Sample Preparation. The uranyl/L² $1 / 1.2$ solutions ( $2 \mathrm{mM})$ was prepared by increasing $\mathrm{pH}$ to 10 with sodium hydroxide $(1 \mathrm{M})$ to solubilize the precipitate formed at acidic condition after mixing the uranyl stock solution and $\mathbf{L}^{2}$ stock solution, then hydrochloride acid (0.1 $\mathrm{M})$ and sodium hydroxide $(0.1 \mathrm{M})$ were used to reach $\mathrm{pH} 3$ and 7.4 . The uranyl/ $\mathbf{L}^{4} 1 / 1.2$ solutions was prepared similarly

EXAFS Data Acquisition Processing and Analysis. EXAFS experiments at the $\mathrm{U}_{\mathrm{III}}\left(\mathrm{E}_{0}=\right.$ $17172.4 \mathrm{eV}$ ) were carried out on the MARS beamline at the SOLEIL synchrotron facility (ring operated at $2.75 \mathrm{GeV}$ with $430 \mathrm{~mA}$ ), which is the French bending magnet beamline dedicated to the study of radioactive materials. ${ }^{49}$ The optics of the beamline essentially consist of a water cooled double crystal monochromator, which is used to select the incident energy of the X-ray beam and for horizontal focalization, and two large water cooled reflecting mirrors that are used for highenergy rejection (harmonic part) and vertical collimation and focalization. ${ }^{50}$ Detection was performed using a Ge multielement fluorescence detector (Ortech). In this case, the monochromator was set with the Si (220) crystals and the mirrors with the Pt strips at 3.1 mrad. All the measurements were recorded in double-layered solution cells (200 $\mu \mathrm{L}$ ) specifically designed for radioactive samples at room temperature. The data were processed by using the ATHENA code. ${ }^{51}$ Background removal was performed by means of a pre-edge linear function. Atomic absorption was simulated with a square-spline function. Phases and amplitudes were calculated with Feff8 code ${ }^{52}$ with the model binding site obtained by the below computational methods. The EXAFS signal extracted was fitted in R space without any additional filtering by 
using the ARTEMIS code. ${ }^{51}$ In all the fits, only one global amplitude factor and one energy threshold factor were considered for all the contributions. Hanning windows with $\mathrm{k}^{3}(2 ; 12)$ and fitting with $\mathrm{R}(1 ; 5)$ were used. Fit parameters such as the amplitude $\left(\mathrm{S}_{0}{ }^{2}\right)$ and $\Delta \mathrm{E}_{0}$ are given for each experiment. The fit $\mathrm{R}$ factor $(\mathrm{r})$ and quality factor reduced- $\chi^{2}\left(\chi^{2}\right.$ iln $)$ are both provided as an indication of the fit quality in the $\mathrm{R}$ space.

\section{Data availability}

Data supporting the findings of this work are available within the paper and its Supplementary Information files.

NMR spectra, plots of potentiometric titration data, plot of the evolution of the absorption spectra and TRLFS of metal competition study, Distances calculated by DFT for the two complexes and deconvolution results of in-vivo protein study are provided as Supplementary Data.

\section{References}

1. Hamilton, J. G. The metabolism of the fission products and the heaviest elements. Radiology 43, 325-343 (1947).

2. Paquet, F. et al. ICRP Publication 130: Occupational Intakes of Radionuclides: Part 1. Ann. ICRP 44, 5-188 (2015).

3. Services, S. Safe handling of radioactive luminous compound. Natl. Bur. Stand. handbook. (1941).

4. Gorden, A. E. V., Xu, J., Raymond, K. N. \& Durbin, P. Rational design of sequestering agents for plutonium and other actinides. Chem. Rev. 103, 4207-4282 (2003).

5. Ansoborlo, É. et al. Review of actinide decorporation with chelating agents. Comptes Rendus Chim. 10, 1010-1019 (2007).

6. Durbin, P. W., Kullgren, B., Ebbe, S. N., Xu, J. \& Raymond, K. N. Chelating agents for uranium(VI): 2. Efficacy and toxicity of tetradentate catecholate and hydroxypyridinonate ligands in mice. Health Phys. 78, 511-521 (2000).

7. Durbin, P. W., Kullgren, B., Xu, J. \& Raymond, K. N. New agents for in vivo chelation of uranium(VI): Efficacy and toxicity in mice of multidentate catecholate and hydroxypyridinonate ligands. Health Phys. 72, 865-879 (1997). 
8. Xu, J. \& Raymond, K. N. Uranyl Sequestering Agents: Correlation of Properties and Efficacy with Structure for UO 2 2+ Complexes of Linear Tetradentate 1-Methyl-3-hydroxy-2(1 H )pyridinone Ligands 1. Inorg. Chem. 38, 308-315 (1999).

9. Sawicki, M. et al. Bisphosphonate sequestering agents. Synthesis and preliminary evaluation for in vitro and in vivo uranium(VI) chelation. Eur. J. Med. Chem. 43, 2768-2777 (2008).

10. H. Henge-Napoli, E. Ansoborlo, V. C, M. et al. Efficacy of ethane-1-hydroxy-1, 1bisphosphonate (EHBP) for the decorporation of uranium after intramuscular contamination in rats. Int. J. Radiat. Biol. 75, 1473-1477 (1999).

11. Abada, S. et al. Phosphonated chelates for nuclear imaging. Org. Biomol. Chem. 12, 9601-20 (2014).

12. Abada, S. et al. Highly relaxing gadolinium based MRI contrast agents responsive to Mg2+ sensing. Chem. Commun. 48, 4085 (2012).

14. Elhabiri, M. et al. Importance of outer-sphere and aggregation phenomena in the relaxation properties of phosphonated gadolinium complexes with potential applications as MRI contrast agents. Chemistry 21, 6535-6546 (2015).

15. Hider, R. C. Design of therapeutic chelating agents. Biochem. Soc. Trans. 30, 751-4 (2002).

16. Makhloufi, A., Frank, W. \& Ganter, C. Diamino- and Mixed Amino-Amido-N-Heterocyclic Carbenes Based on Triazine Backbones. Organometallics 31, 2001-2008 (2012).

17. Aboussafy, C. L. \& Clive, D. L. J. A Dieckmann Cyclization Route to Piperazine-2,5-diones. J. Org. Chem. 77, 5125-5131 (2012).

18. Smeyers-Verbeke, J. Data fitting in the chemical sciences by the method of least squares, by Peter Gans. Chemom. Intell. Lab. Syst. 19, 343 (1993).

19. Gans, P. et al. Hyperquad2000.

20. Gans, P., Sabatini, A. \& Vacca, A. Investigation of equilibria in solution. Determination of equilibrium constants with the HYPERQUAD suite of programs. Talanta 43, 1739-1753 (1996).

21. Perlmutter-Hayman, B. Cooperative Binding to Macromolecules. A Formal Approach. Acc. Chem. Res. 19, 90-96 (1986).

22. Ischikawa. Structure and NMR behavior complex Co with aminophosphonate.pdf. (1997).

23. Ichikawa, T. \& Sawada, K. Protonation Behavior and Intramolecular Interactions of $\alpha, \omega-$ Alkanediaminepolymethylenepolyphosphonates. Bulletin of the Chemical Society of Japan 70, 829-835 (1997).

24. Union, I. et al. COMMISSION ON EQUILIBRIUM DATA * CRITICAL EVALUATION OF STABILITY CONSTANTS OF PHOSPHONIC ACIDS ** ( IUPAC Technical Report ) Critical evaluation of stability constants of phosphonic acids ( IUPAC Technical Report ). 73, 1641-1677 (2001).

25. Lukeš, I., Kotek, J., Vojtíšek, P. \& Hermann, P. Complexes of tetraazacycles bearing methylphosphinic/phosphonic acid pendant arms with copper(II), zinc(II) and lanthanides(III). A comparison with their acetic acid analogues. Coord. Chem. Rev. 216-217, 287-312 (2001).

26. Pellegatti, L. et al. Pyridine-based lanthanide complexes: towards bimodal agents operating as near infrared luminescent and MRI reporters. Chem. Commun. 0, 6591 (2008).

27. Gillet, R. et al. A Bispidol Chelator with a Phosphonate Pendant Arm: Synthesis, Cu(II) Complexation, and64Cu Labeling. Inorg. Chem. 56, 11738-11752 (2017). 
28. Abada, S. et al. Highly stable acyclic bifunctional chelator for 64Cu PET imaging. Radiochim. Acta 99, 663-678 (2011).

29. Brulfert, F. et al. Structural Environment and Stability of the Complexes Formed between Calmodulin and Actinyl Ions. Inorg. Chem. 55, 2728-2736 (2016).

30. Koban, A. \& Bernhard, G. Uranium(VI) complexes with phospholipid model compounds - A laser spectroscopic study. J. Inorg. Biochem. 101, 750-757 (2007).

31. Catalano, J. G. \& Brown, G. E. Analysis of uranyl-bearing phases by EXAFS spectroscopy: Interferences, multiple scattering, accuracy of structural parameters, and spectral differences. Am. Mineral. 89, 1004-1021 (2004).

32. Thompson, H. A., Brown, G. E., Parks, G. A., Brown Jr, G. E. \& Parks, G. A. XAFS spectroscopic study of uranyl coordination in solids and aqueous solution. Am. Mineral. 82, 483-496 (1997).

33. Sauge-Merle, S. et al. Structural Analysis of Uranyl Complexation by the EF-Hand Motif of Calmodulin: Effect of Phosphorylation. Chem. - A Eur. J. 23, 15505-15517 (2017).

34. Pardoux, R. et al. Modulating Uranium Binding Affinity in Engineered Calmodulin EF-Hand Peptides: Effect of Phosphorylation. PLoS One 7, e41922 (2012).

35. Marcin, S. et al. Discovery of powerful uranyl ligands from efficient synthesis and screening. Chem. - A Eur. J. 11, 3689-3697 (2005).

36. Migianu-Griffoni, E. et al. Design and synthesis of new polyphosphorylated upper-rim modified calix[4]arenes as potential and selective chelating agents of uranyl ion. Tetrahedron 65, 1517-1523 (2009).

37. Brulfert, F. thesis Mécanisme d'interaction des actinides avec une protéine : la calmoduline. (2016).

38. Brulfert, F. et al. Enzymatic activity of the CaM-PDE1 system upon addition of actinyl ions. J. Inorg. Biochem. 172, 46-54 (2017).

39. Anthony-Cahill, S. J. et al. Molecular characterization of helix-loop-helix peptides. Science 255, 979-83 (1992).

40. American Society of Biological Chemists., G. B., Rockefeller Institute for Medical Research., H. A. \& American Society for Biochemistry and Molecular Biology. The Journal of biological chemistry. Journal of Biological Chemistry 111, (American Society for Biochemistry and Molecular Biology, 1935).

41. Al-Shawi, M. K., Parsonage, D. \& Senior, A. E. Thermodynamic Analyses of the Catalytic Pathway of FI-ATPase from Escherichia coli. J. Biol. Chem. 265, 4402-4410 (1990).

42. Leydier, A. et al. Sequestering agents for uranyl chelation: new calixarene ligands. Tetrahedron 64, 11319-11324 (2008).

43. Hugo E. Gottlieb, * et al. NMR chemical shifts of common laboratory solvents as trace impurities. J. Org. Chem. 62, 7512-7515 (1997).

44. Patiny, L. \& Borel, A. ChemCalc: A building block for tomorrow's chemical infrastructure. J. Chem. Inf. Model. 53, 1223-1228 (2013).

45. Frisch, M. J. et al. Gaussian 09; Gaussian, Inc. Wallingford, CT 32, 5648-5652 (2009).

46. Lee, C., Yang, W. \& Parr, R. G. Becke’s Three Parameter Hybrid Method Using the LYP. Phys. Rev. B 37, 785 (1988).

47. Küchle, W., Dolg, M., Stoll, H. \& Preuss, H. Energy-adjusted pseudopotentials for the actinides. Parameter sets and test calculations for thorium and thorium monoxide. J. Chem. Phys. 100, 7535-7542 (1994). 
48. Barone, V. \& Cossi, M. Quantum calculation of molecular energies and energy gradients in solution by a conductor solvent model. J. Phys. Chem. A 102, 1995-2001 (1998).

49. Sitaud, B., Solari, P. L., Schlutig, S., Llorens, I. \& Hermange, H. Characterization of radioactive materials using the MARS beamline at the synchrotron SOLEIL. in Journal of Nuclear Materials 425, 238-243 (North-Holland, 2012).

50. Solari, P. L., Schlutig, S., Hermange, H. \& Sitaud, B. MARS, a new beamline for radioactive matter studies at SOLEIL. in Journal of Physics: Conference Series 190, 012042 (IOP Publishing, 2009).

51. Ravel, B. \& Newville, M. ATHENA, ARTEMIS, HEPHAESTUS: Data analysis for X-ray absorption spectroscopy using IFEFFIT. in Journal of Synchrotron Radiation 12, 537-541 (International Union of Crystallography, 2005).

52. Rehr, J. J. \& Albers, R. C. Theoretical approaches to x-ray absorption fine structure. Rev. Mod. Phys. 72, 621-654 (2000). 